\title{
Productivity and gas exchanges of the common bean subjected to inoculation and nitrogen fertilization
}

\author{
Produtividade e trocas gasosas do feijoeiro comum submetido à inoculação e fertilização com \\ nitrogênio
}

Productividad e intercambios de gases del frijol común sometido a inoculación y fertilización con nitrógeno

Amanda Magalhães Bueno

ORCID: https://orcid.org/0000-0001-8830-1040 Universidade Federal de Goiás, Brasil

E-mail: amanda.mabu@gmail.com

Rilner Alves Flores

ORCID: https://orcid.org/0000-0002-6484-7150 Universidade Federal de Goiás, Brasil

E-mail: rilner@ufg.br

Enderson Petrônio de Brito Ferreira

ORCID: https://orcid.org/0000-0002-1964-1516 Embrapa Arroz e Feijão, Brasil

E-mail: enderson.ferreira@embrapa.br

Aline Franciel de Andrade

ORCID: https://orcid.org/0000-0001-8231-553X Universidade Federal de Goiás, Brasil

E-mail: alineandrade418@gmail.com

Frederico Raimundo Simões de Lima

ORCID: https://orcid.org/0000-0002-5669-0034 Universidade Federal de Goiás, Brasil

E-mail: fredlimaufg@yahoo.com.br

Marco Aurélio Pessoa-de-Souza

ORCID: https://orcid.org/0000-0002-1367-8510

Universidade Federal de Goiás, Brasil E-mail: mpessoa@ufg.br

José Alves Júnior

ORCID: https://orcid.org/0000-0002-1187-3275

Universidade Federal de Goiás, Brasil

E-mail: josealvesufg@yahoo.com.br

Marcio Mesquita

ORCID: https://orcid.org/0000-0002-0271-9751 Universidade Federal de Goiás, Brasil

E-mail: marcio.mesquita@ufg.br

\begin{abstract}
Beans are one of the main foods consumed in Brazil. It is considered an essential ingredient in the basic diet of Brazilians. As a management practice, aiming to supply $\mathrm{N}$ and increase crop productivity, producers have used the association of seed inoculation with nitrogen fertilization. Thus, the objective of this study is to evaluate the effects of split nitrogen fertilization and seed inoculation on common bean productivity. The experiment was carried out in completely randomized blocks and a $2 \times 2 \times 3$ factorial design with four replications. The first factor was seed inoculation (presence or absence) with peat inoculant containing the strains SEMIA 4077 and SEMIA 4080 from $R$. tropici and the strain SEMIA 4088 from $R$. freirei. The second factor was the parceling of nitrogen cover fertilization $\left(80+40\right.$ and $60+60 \mathrm{~kg} \mathrm{ha}^{-1}$ of $\mathrm{N}$ at 20 and 40 days after emergence (DAE)). The third factor was time of assessment $(50,65$ and $80 \mathrm{DAE})$. The inoculated bean showed a 5\% higher leaf $\mathrm{N}$ content than non-inoculated ones. Transpiration and liquid photosynthesis rates were higher in inoculated plants and in those with $60+60 \mathrm{~kg} \mathrm{ha}^{-1}$ of $\mathrm{N}$. However, productivity was $13 \%$ higher in uninoculated beans regardless of nitrogen fertilization.
\end{abstract}

Keywords: Biological nitrogen fixation; Phaseolus vulgaris L.; Plant mineral nutrition; Plant physiology.

\section{Resumo}

O feijão é um dos principais alimentos consumidos no Brasil. É considerado ingrediente essencial na dieta básica do brasileiro. Como prática de manejo, visando fornecer $\mathrm{N}$ e aumentar a produtividade das lavouras, os produtores têm 
utilizado a associação da inoculação de sementes à fertilização com nitrogênio. Assim, o objetivo deste trabalho é avaliar os efeitos da fertilização nitrogenada parcelada e da inoculação de sementes na produtividade do feijoeiro. $O$ experimento foi conduzido em blocos ao acaso e em esquema fatorial 2x2x3 com quatro repetições. O primeiro fator foi a inoculação das sementes (presença ou ausência) com inoculante turfoso contendo as cepas SEMIA 4077 e SEMIA 4080 de $R$. tropici e a cepa SEMIA 4088 de $R$. freirei. O segundo fator foi o parcelamento da adubação com cobertura de nitrogênio $\left(80+40\right.$ e $60+60 \mathrm{~kg} \mathrm{ha}^{-1}$ de $\mathrm{N}$ aos 20 e 40 dias após a emergência (DAE)). O terceiro fator foi o tempo de avaliação (50, 65 e 80 DAE). O feijão inoculado apresentou teor de $\mathrm{N}$ foliar $5 \%$ maior do que o não inoculado. As taxas de transpiração e fotossíntese líquida foram maiores nas plantas inoculadas e naquelas com $60+$ $60 \mathrm{~kg} \mathrm{ha}^{-1}$ de $\mathrm{N}$. No entanto, a produtividade foi $13 \%$ maior nos grãos não inoculados independentemente da fertilização com nitrogênio.

Palavras-chave: Fisiologia vegetal; Fixação biológica de nitrogênio; Nutrição mineral de plantas; Phaseolus vulgaris L.

\section{Resumen}

Los frijoles son uno de los principales alimentos consumidos en Brasil. Se considera un ingrediente esencial en la dieta básica de los brasileños. Como práctica de manejo, con el objetivo de suministrar $\mathrm{N}$ y aumentar la productividad de los cultivos, los productores han utilizado la asociación de la inoculación de semillas con la fertilización con nitrógeno. Por lo tanto, el objetivo de este estudio es evaluar los efectos de la fertilización con nitrógeno dividido y la inoculación de semillas sobre la productividad del frijol común. El experimento se realizó en bloques completamente al azar y un diseño factorial 2x2x3 con cuatro repeticiones. El primer factor fue la inoculación de semillas (presencia o ausencia) con inoculante de turba que contenía las cepas SEMIA 4077 y SEMIA 4080 de $R$. tropici y la cepa SEMIA 4088 de $R$. freirei. El segundo factor fue la parcelación de la fertilización de la cubierta de nitrógeno $(80+40$ y $60+60 \mathrm{~kg} \mathrm{ha}^{-1}$ de $\mathrm{N}$ a los 20 y 40 días después de la emergencia (DAE)). El tercer factor fue el tiempo de evaluación (50, 65 y 80 DAE). El frijol inoculado mostró un contenido de $\mathrm{N}$ en hojas $5 \%$ más alto que los no inoculados. Las tasas de transpiración y fotosíntesis líquida fueron mayores en plantas inoculadas y en aquellas con 60 $+60 \mathrm{~kg} \mathrm{ha}^{-1}$ de N. Sin embargo, la productividad fue $13 \%$ mayor en frijoles sin inocular independientemente de la fertilización con nitrógeno.

Palabras clave: Fijación biológica de nitrógeno; Fisiología de las plantas; Nutrición mineral vegetal; Phaseolus vulgaris $\mathrm{L}$

\section{Introduction}

Common beans (Phaseolus vulgaris L.) have a short growth cycle as compared to other grain producing crops. It is one of the most important crops in the tropical savanna of Brazil (Flores et al., 2017, 2018 and 2019). It is communally sown in the winter season with irrigation support. Due its nutritional composition, it is an important protein source, especially for the poorest population. The adequate balance between water and fertilization makes this one of the most productive crops in Brazil, resulting in high volumes (above 3,000 $\mathrm{kg} \mathrm{ha}^{-1}$ ) (Azevedo et al., 2008; Flores et al., 2017, 2018 and 2019 ).

Nitrogen is an essential nutrient due to be highly demanded, since common beans have expressive contents of amino acids. As such, $\mathrm{N}$ is the most required nutrient (Fageria \& Baligar, 2005). It is supplied by mineralization of organic matter (Gilmour \& Mauromoustakos, 2011). Also, nitrogen has a complex dynamic in agroecosystems because it can be found in nature in seven different chemical forms. Thus, it is hard to manage (dos Santos et al., 2003) and essential to productivity (Carvalho et al., 2001).

The application of mineral $\mathrm{N}$ in tropical soils can result in a low efficiency of response by common bean crops (Piaskowski et al., 2001). However, Ferreira et al, (2000) stated that $\mathrm{N}$ application to common beans produces several responses according to geographic regions in Brazil. It is not considered a variation among different climates, phytosanitary pressure, and cultural management. Nitrogen is also essential because it can pose some risks to the environment due to leaching and underground contamination (Walter et al., 2016).

The biological $\mathrm{N}_{2}$ fixation (BNF) due to the association to bacteria of the genus Rhizobium has been reported in the literature as a viable alternative to supply $\mathrm{N}$ because it is a biological form of this nutrient (Oliveira et al., 2017). The ecological relationship between the organism and the plant promotes carbohydrates exchange from plants and nitrogen by rhizobia (Epstein \& Bloom, 2004). After this association succeeds, some ecological pieces of evidence appear, such as nodules 
(Rocha, 2007).

According to Moreira et al. (2017), beans inoculated with efficient rhizobia strains can fix $70 \pm 5.8 \%$ of nitrogen from the air. This phenomenon may represent around $920.23 \pm 117.32 \mathrm{mg}$ of $\mathrm{N}$ per plant, which means an input of $130 \pm 70 \mathrm{~kg} \mathrm{ha}^{-1}$ of $\mathrm{N}$ to the crop (Ferreira et al., 2000; Moreira et al., 2017). Seed inoculation with mineral nitrogen is a strategy to improve productivity results. Pacheco et al. (2012) suggested a combination between inoculation of bean seeds and the topdressing application of $40 \mathrm{~kg} \mathrm{ha}^{-1}$ of $\mathrm{N}$. This combination provides accumulation of $\mathrm{N}$ in grains and productive yields equivalent to fertilization with $60 \mathrm{~kg} \mathrm{ha}^{-1}$ of $\mathrm{N}$.

The objective of the present study was to evaluate the effects of seed inoculation and split nitrogen fertilization on physiology of gas exchange, photochemical efficiency of photosystem II, and productivity of common beans grown under irrigated systems in the Brazilian Cerrado region.

\section{Methodology}

\subsection{Characterization of the experimental area}

The experiment was carried out at the Agronomy College of the Federal University of Goiás under the geographical coordinates $16^{\circ} 35^{\prime} 48.27^{\prime \prime} \mathrm{S}$ and $49^{\circ} 16^{\prime} 38.21^{\prime \prime} \mathrm{W}, 736 \mathrm{~m}$ altitude and 1,438.00 mm of average annual rainfalls (Casaroli et al., 2018), and hydric management by a central pivot irrigation system. According to the Köppen classification, the climate is Aw (tropical savanna) with two well-defined seasons: a dry season (April to September) and a rainy season (October to March) (Alvares et al., 2013). The regular climatic data were collected and presented in Figure 1. The experiment was conducted between June and September 2019.

Figure 1. Air temperature maximum (TM), minimum (Tm) and average (Ta), and rainfall per month, from January/2017 to December/2017, in the College of Agronomy, Federal University of Goiás, Goiânia, GO, Brazil.

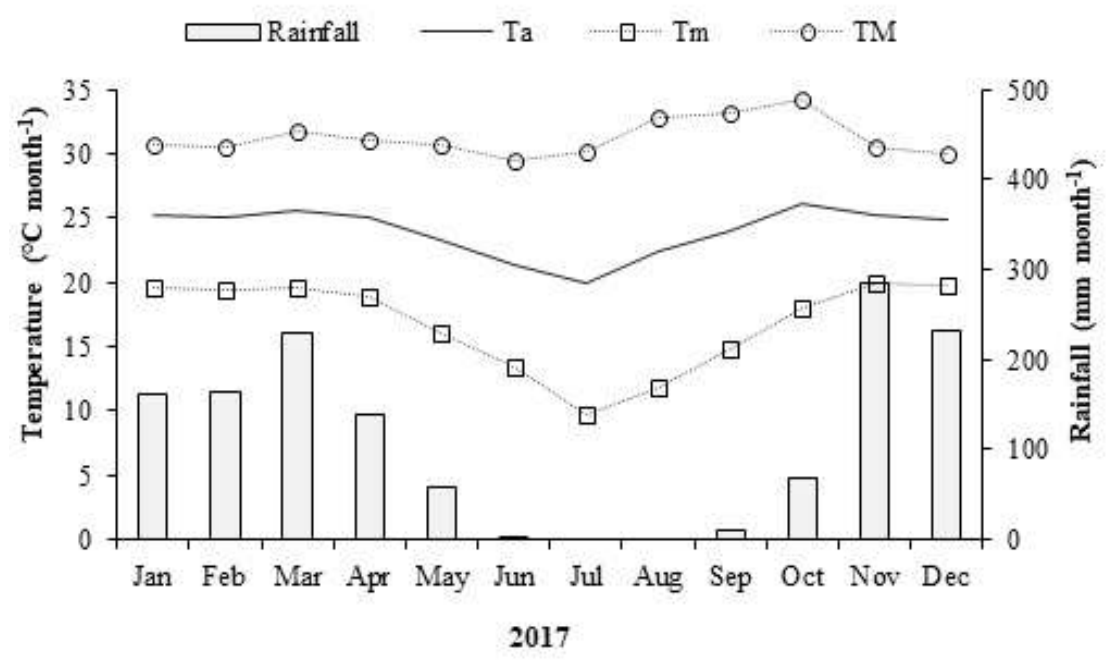

Source: Authors.

\subsection{Experimental design}

The experiment was addressed to a randomized block design with a $2 \times 2 \times 3$ factorial arrangement and four replicates. The experimental plots were composed by five lines of $4 \mathrm{~m}$ spaced $0.45 \mathrm{~m}$ apart. The first factor was the presence or absence of Rhizobium inoculation before sowing. In the treatment with inoculation, the seeds were pre-moistened with a $10 \%$ sugar solution (10 g of sugar, $100 \mathrm{ml}$ of water) at a ratio of $300 \mathrm{ml}$ for $50 \mathrm{~kg}$ of seeds. After moistening, the peat inoculant containing 
a blend of the strains SEMIA 4077 and SEMIA 4080 of Rhizobium tropici and the strain SEMIA 4088 of $R$. freirei was applied to seeds in an amount corresponding to two doses per hectare.

The second factor was the parceling of nitrogen input. $120 \mathrm{~kg} \mathrm{ha}^{-1}$ of urea $\mathrm{N}$ were subdivided into $80+40 \mathrm{~kg} \mathrm{ha}^{-1}$ of urea $\mathrm{N}$ at 20 and $40 \mathrm{DAE}$ (days after emergence) or $60+60 \mathrm{~kg} \mathrm{ha}^{-1}$ of $\mathrm{N}$ at 20 and $40 \mathrm{DAE}$, respectively. The commercial product was a source with a low solubility (isobutyledene diurea - IBDU). The last factor was evaluation day after emergence (DAE): 50, 65, and 80 DAE. Along this evaluation, some physiological data were collected to analyze plant behavior (see 2.5 section). In addition, at the end of the crop cycle, productivity was measured.

\subsection{Experimental field}

The sowing was carried out using a minimum cultivation system in June, during the tropical winter season. The seed (cv. Pérola) produces $95 \%$ of germination. The planting procedure was carried out with 16 seed linear meter ${ }^{-1}$ for a population of 333.333 plants ha ${ }^{-1}$. The seed treatment against plant pathogens was performed by applying $200 \mathrm{~g}$ of a commercial product $100 \mathrm{~kg}^{-1}$ of seeds. The formulation is an insecticide based on thiamethoxam. The weeding control was manual.

\subsection{Assessments of the nutritional status of common beans}

The nutritional status of plants was analyzed following the factor time (50, 65, and $80 \mathrm{DAE})$. The parameters evaluated were relative chlorophyll index (RCI) (following Barbosa et al. (2008) (Barbosa Filho et al., 2008)) using a Falker ${ }^{\circledR}$ chlorophyll meter, ClorofiLOG CFL 1030. In each plot, five random plants were selected. The first fully expanded leaf from the apex of the main stem was selected. The first completely developed leaflet was selected.

Along with the development of common beans, leaf tissue sampling was carried out at 50,65 and 80 DAE to evaluate $\mathrm{N}$ content. The third fully expanded leaf from the apex of the main stem was collected, totaling 20 leaves per plot, according to the methodology described by Ambrosano et al. (1997) and Malavolta et al. (1997). Total N content was measured according to the methodology proposed by Silva (2009).

\subsection{Assessments of the physiological attributes of common bean gas exchange}

The gas exchange was analyzed using an infrared gas analyzer (IRGA) attached to an integrated fluorometer and gas exchange system [iFL] following the factor time (50, 65, and $80 \mathrm{DAE})$. The analysis was performed between 8:00 and 10:00 AM on the third fully expanded leaf due to a better condition of liquid photosynthesis.

Plants were selected at random within each plot. The evaluated factors were net photosynthesis rate (A), stomatal conductance (Gs), transpiration (E), internal $\mathrm{CO}_{2}$ concentration $\left(\mathrm{C}_{\mathrm{i}}\right)$, and photosystem II photochemical efficiency ( $\left.\mathrm{Fv} / \mathrm{Fm}\right)$.

\subsection{Root nodulation and grain yield evaluations of common bean}

The nodulation evaluations were conducted at the reproductive stage R6. The number of nodules (NN) and dry nodule mass (NDM) per plant were determined according to Moreira et al. (2017). After the production cycle (96 days), the crop was harvested manually, impurities were removed, and productivity was measured. The two central lines, excluding 0.5 meters around, were considered as the useful area, totaling $0.9 \mathrm{~m}^{2}$. The grains were weighed, and productivity was determined in $\mathrm{kg}$ $\mathrm{ha}^{-1}$.

\subsection{Statistical analysis}

An analysis of variance was performed using the $\mathrm{F}$ test at $5 \%$ and $1 \%$ probability. When the $\mathrm{F}$ values were statistically significant, the means of qualitative data were compared by Tukey test at $5 \%$ probability. For significant quantitative data, a 
polynomial regression analysis was performed. The choice of the regression model was based on the significance of regression coefficients and the highest value of the determination coefficient. The software used was AgroEstat (Barbosa \& Maldonado Júnior, 2015).

\section{Results}

\subsection{Nutritional status and maximum photochemical efficiency of common bean photosystem II}

The inoculation of seeds promoted a high relative chlorophyll index regardless of nitrogen fertilization split and evaluation period (Table 1). Data show that the $\mathrm{RCI}\left(\mu \mathrm{g} \mathrm{cm}^{-2}\right)$ generally behaves significantly differently regarding the inoculation factor (Table 1). Figure 2a shows a marked behavior of the treatment without inoculation and $80+40 \mathrm{~kg} \mathrm{~N} \mathrm{ha}^{-1}$.

Table 1. Relative chlorophyll index, leaf $N$ content, and photochemical efficiency of photosystem II ( $\mathrm{Fv} / \mathrm{Fm})$ of common bean (Phaseolus vulgaris L.) as a function of seed inoculation split nitrogen fertilization and evaluation period.

\begin{tabular}{lccc}
\hline Treatments & Relative chlorophyll index & Leaves N content & Fv/Fm \\
\hline Inoculation (I) & $\mu \mathrm{g} \mathrm{cm}^{-2}$ & $\mathrm{~g} \mathrm{~kg}^{-1}$ & - \\
Negative (NI) & $55.46 \mathrm{~b}$ & $42.72 \mathrm{~b}$ & $0.75 \mathrm{a}$ \\
Positive (PI) & $57.33 \mathrm{a}$ & $45.10 \mathrm{a}$ & $0.74 \mathrm{~b}$ \\
F-test & $22.00^{* *}$ & $11.37^{* *}$ & $14.69^{* *}$ \\
Subdivision of N (N) & & & \\
{$[60+60]$} & $55.88 \mathrm{~b}$ & $43.48 \mathrm{a}$ & $0.75 \mathrm{a}$ \\
{$[80+40]$} & $56.92 \mathrm{a}$ & $44.34 \mathrm{a}$ & $0.74 \mathrm{~b}$ \\
F-test & $5.25^{*}$ & $1.49^{\mathrm{ns}}$ & $6.88^{*}$ \\
Evaluation Period (T) & & & \\
50 DAE & $53.09 \mathrm{c}$ & $50.58 \mathrm{a}$ & $0.75 \mathrm{a}$ \\
65 DAE & $56.34 \mathrm{~b}$ & $45.50 \mathrm{~b}$ & $075 \mathrm{a}$ \\
80 DAE & $59.75 \mathrm{a}$ & $35.65 \mathrm{c}$ & $0.73 \mathrm{~b}$ \\
F-test & $71.47^{* *}$ & $154.89^{* *}$ & $7.54^{* *}$ \\
Interaction IxN - F & $30.68^{* *}$ & $0.05^{\mathrm{ns}}$ & $1.99^{\mathrm{ns}}$ \\
Interaction IxT - F & $4.35^{*}$ & $3.10^{\mathrm{ns}}$ & $2.15^{\mathrm{ns}}$ \\
Interaction NxT - F & $2.62^{\mathrm{ns}}$ & $0.12^{\mathrm{ns}}$ & $19.72^{* *}$ \\
Interaction IxTxN - F & $0.21^{\mathrm{ns}}$ & $1.89^{\mathrm{ns}}$ & $6.48^{* *}$ \\
\hline Mean General & 56.39 & 43.91 & 0.74 \\
C.V (\%) & 2.79 & 5.55 & 1.91 \\
\hline
\end{tabular}

Means followed by the same letter on the line do not differ by Tukey's test at $5 \%$ probability, C.V: Coefficient of variation $* * ; *$ and ns significant at $1 \%, 5 \%$ and non-significant $5 \%$ probability by the F-test, respectively. Source: Authors.

The combination without application of inoculant and the high $\mathrm{N}$ input in the first steps of crop production resulted in high levels of the RCI parameter. Table 1 shows that statistical difference $(F=5.25)$, even if all treatments increase along time (Figure 2a). Therefore, data show that plants with inoculation treatment presented a physiological stress higher than the treatments without inoculation (Figure 2 a Table 1).

Specifically, on the treatment with $80-40 \mathrm{~kg} \mathrm{ha}^{-1}$ at 50 and $65 \mathrm{DAE}$, plants presented a higher RCI (relative chlorophyll index) mean $\left(56.92 \mu \mathrm{g} \mathrm{cm}^{-2}\right.$ ) (Table 1). As crop production time went by in the field, the RCI showed a significant increase. It reached $59.75 \mu \mathrm{g} \mathrm{cm}^{-2}$ at $80 \mathrm{DAE}$. This result means an improvement of $12.5 \%$ compared with that at $50 \mathrm{DAE}$ 
(Table 1) whatever the inoculation and $\mathrm{N}$ application factors. Among the factors of this study, inoculation and time factor were the most statistically significant (Table 1).

The Fv/Fm index showed significant results for all treatments (Table 1). Plants without inoculation had a lower stress ratio compared than that of the inoculation treatment. The $\mathrm{N}$ application also showed a different stress value for common beans. The $60+60$ split reached a better ratio than the $80+40 \mathrm{~kg} \mathrm{ha}^{-1}$ ratio of $\mathrm{N}$ at 20 and $40 \mathrm{DAE}$. Time did not affect this indicator up to 65 DAE. However, thereafter plants demonstrated some stress (Table 1).

We tested the interaction among the factors and observed significant differences mainly in nitrogen, time, and all factors combined (Table 1). Leaf $\mathrm{N}$ content was not significant nor did it interact. Figure 2 -right shows these results. The color scale of Figure $2 \mathrm{~b}$ demonstrates no significant interaction among the factors of this study. Only the inoculated treatment $\left(80+40 \mathrm{~kg} \mathrm{ha}^{-1}\right.$ of $\mathrm{N}$ at 20 and $\left.40 \mathrm{DAE}\right)$ had an Fv/Fm ratio above the experimental mean. The factor time does not affect Fv/Fm dynamics.

Figure 2. Interaction effects among treatments (positive inoculation - PI and negative inoculation - NI, and N parceling [60+60] or [80+40] kg ha-1 of $\mathrm{N}$ urea), time, and relative chlorophyll index (RCI) (a) and photochemical efficiency of photosystem II (Fv/Fm) (b) of common beans (Phaseolus vulgaris L.). Average data on surface design. Red and blue represent low and high values, respectively.

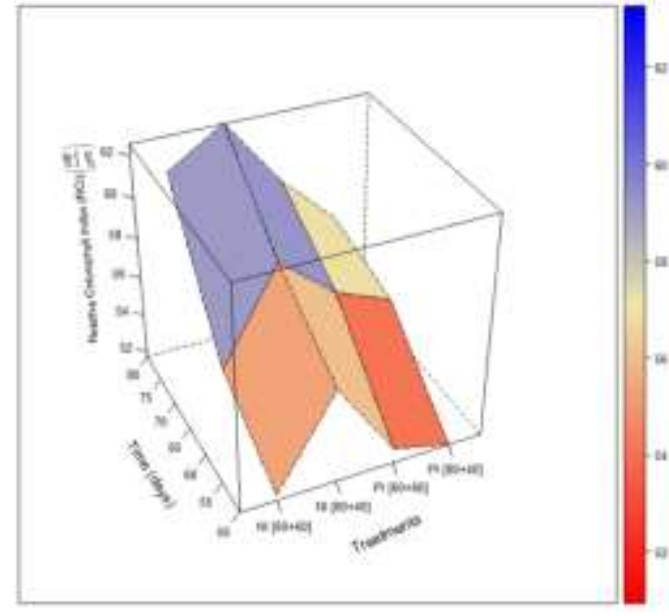

(a)

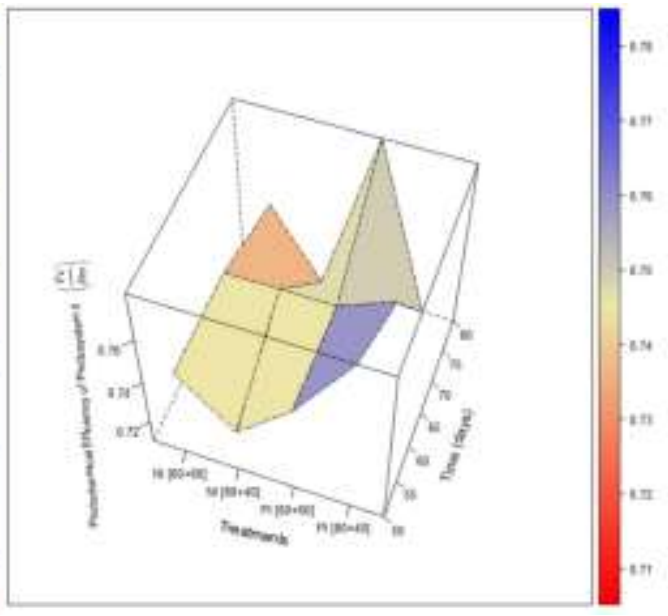

(b)

Source: Authors.

Leaf $\mathrm{N}$ content was significant between inoculation and time, but not with $\mathrm{N}$ input. No interactions were statistically significant for $\mathrm{N}$ content. As time passed, the final content was even lower. The presence of inoculation evidenced a 5.3\% higher nitrogen content in leaves $\left(45.10 \mathrm{~g} \mathrm{~kg}^{-1}\right)$ than in the absence of inoculation $\left(42.72 \mathrm{~g} \mathrm{~kg}^{-1}\right)$. At the same time, considering the factor time, nitrogen decreases along with the development of crop production. This behavior was expected: $29.51 \%$ decreased along the evaluations of this experiment (Table 1).

\subsection{Physiological attributes of common bean gas exchange}

Transpiration response was statistically significant in the inoculation treatment. The non-inoculated treatments had a transpiratory rate of $4.52 \mathrm{~mol} \mathrm{~m}^{-2} \mathrm{~s}^{-1}$, about $35.33 \%$ lower than the rate found for inoculated plants $\left(6.99 \mathrm{~mol} \mathrm{~m}^{-2} \mathrm{~s}^{-1}\right)$. Transpiration behaved differently with $\mathrm{N}$ input: $60+60 \mathrm{~kg} \mathrm{ha}^{-1}$ at 20 and 40 DAE showed a transpiratory rate of $6.28 \mathrm{~mol} \mathrm{~m}^{-2} \mathrm{~s}^{-}$ 
${ }^{1}$, which is $16.71 \%$ higher than plants submitted to the $80+40 \mathrm{~kg} \mathrm{ha}^{-1}$ split at 20 and 40 DAE. This study also demonstrates a time effect on transpiration which is more intense at the start of growth (50 DAE) (Table 2).

Stomatal conductance followed a similar behavior to transpiration among factors of this study, with a highlight to the inoculated treatment. As observed for "E" response, $60+60 \mathrm{~kg} \mathrm{ha}^{-1}$ had the best timing between treatments. Finally, as time as passed, conductance decreased (Table 2).

The results of the net photosynthesis rate (A) were significant in $\mathrm{N}$ parceling and time. Otherwise, inoculation did not present a change in this parameter. Again, the 60+60 input was the most expressive in influencing net photosynthesis rate (8.74 $\mu \mathrm{mol} \mathrm{m} \mathrm{m}^{-2} \mathrm{~s}^{-1}$ ). It was $13.15 \%$ higher than the other treatments. The behavior of net photosynthesis rate within the evaluation period was linear and decreasing. It presented a rate of $11.01 \mu \mathrm{mol} \mathrm{m} \mathrm{m}^{-2} \mathrm{~s}^{-1}$ at $50 \mathrm{DAE}$, decreasing to $7.81 \mu \mathrm{mol} \mathrm{m}^{-2} \mathrm{~s}^{-1}$ at 65 DAE, until reaching $5.68 \mu \mathrm{mol} \mathrm{m}^{-2} \mathrm{~s}^{-1}$ at $80 \mathrm{DAE}$ (Table 2).

Table 2. Transpiration (E), stomatal conductance (Gs), liquid photosynthesis rate (A), and internal $\mathrm{CO}_{2}$ concentration (Ci), of common bean (Phaseolus vulgaris L.) as a function of seed inoculation, split nitrogen fertilization and evaluation period.

\begin{tabular}{lcccc}
\hline Treatments & $\mathrm{E}$ & $\mathrm{Gs}$ & $\mathrm{A}$ & $\mathrm{Ci}$ \\
\hline Inoculation (I) & $\mathrm{mol} \mathrm{m}^{-2} \mathrm{~s}^{-1}$ & $\mathrm{~mol} \mathrm{~m}^{-2} \mathrm{~s}^{-1}$ & $\mu \mathrm{mol} \mathrm{m}^{-2} \mathrm{~s}^{-1}$ & $\mu \mathrm{mol} \mathrm{mol}^{-1}$ \\
Negative (NI) & $4.52 \mathrm{~b}$ & $0.24 \mathrm{~b}$ & $8.39 \mathrm{a}$ & $315.37 \mathrm{a}$ \\
Positive (PI) & $6.99 \mathrm{a}$ & $0.26 \mathrm{a}$ & $7.93 \mathrm{a}$ & $315.37 \mathrm{a}$ \\
F-test & $120.03^{* *}$ & $6.19^{*}$ & $1.83^{\mathrm{ns}}$ & $0.39^{\mathrm{ns}}$ \\
Subdivision of N (N) & & & & \\
{$[60+60]$} & $6.28 \mathrm{a}$ & $0.26 \mathrm{a}$ & $8.70 \mathrm{a}$ & $310.87 \mathrm{a}$ \\
{$[80+40]$} & $5.23 \mathrm{~b}$ & $0.24 \mathrm{~b}$ & $7.59 \mathrm{~b}$ & $324.54 \mathrm{a}$ \\
F-test & $21.71^{* *}$ & $4.96^{*}$ & $11.32^{* *}$ & $3.38^{\mathrm{ns}}$ \\
Evaluation Period (E) & & & & \\
50 DAE & $7.59 \mathrm{a}$ & $0.36 \mathrm{a}$ & $11.01 \mathrm{a}$ & $329.12 \mathrm{a}$ \\
65 DAE & $4.55 \mathrm{~b}$ & $0.26 \mathrm{~b}$ & $7.81 \mathrm{~b}$ & $311.37 \mathrm{a}$ \\
80 DAE & $5.13 \mathrm{~b}$ & $0.14 \mathrm{c}$ & $5.68 \mathrm{c}$ & $312.62 \mathrm{a}$ \\
& $68.05^{* *}$ & $178.78^{* *}$ & $83.28^{* *}$ & $2.37^{\mathrm{ns}}$ \\
F-test & $2.95^{\mathrm{ns}}$ & $61.04^{* *}$ & $8.20^{* *}$ & $3.85^{\mathrm{ns}}$ \\
Interaction IxN $-\mathbf{F}$ & $3.66^{* *}$ & $21.66^{* *}$ & $2.38^{\mathrm{ns}}$ & $0.97^{\mathrm{ns}}$ \\
Interaction IxE $-\mathbf{F}$ & $2.50^{\mathrm{ns}}$ & $6.28^{* *}$ & $9.06^{* *}$ & $1.46^{\mathrm{ns}}$ \\
Interaction NxE - F & $41.06^{* *}$ & $17.41^{* *}$ & $14.18^{* *}$ & $0.12^{\mathrm{ns}}$ \\
Interaction IxExN - F & 5.75 & 0.25 & 8.16 & 317.70 \\
\hline Mean General & 13.58 & 12.93 & 14.39 & 8.10 \\
C.V $(\%)$ & & & & \\
\hline
\end{tabular}

Means followed by the same letter on the line do not differ by Tukey's test at $5 \%$ probability, C.V: Coefficient of variation $* * ; *$ and ns significant at $1 \%, 5 \%$, and non-significant $5 \%$ probability by the F-test, respectively. Source: Authors.

Figure 3a shows the performance of net photosynthesis (A). It was possible to note effects of time throughout the experiment. Inoculation effects were not statistically significant. Figure 3a shows this dynamic. In the other hand, Table 2 shows a significant difference between $\mathrm{N}$ parceling and confirms the performance values. It is thus possible to confirm a type of buffer effect of inoculated treatments (PI) over time. Regarding a different performance, the non-inoculated treatment (NI) presented a variation more expressive than first group's. Despite these effects over time, the general tendency of this essay showed only a subtle variation. 
Stomatal conductance (Gs) was statistically significant for all factors and interactions (Table 2). The data also demonstrate that time was the most significant factor among all factors for Gs. However, it is important to point out that PI factors were stable for all conditions over time (Figureb). The negative inoculant (NI) treatment began with high responses of Gs. As time passed, this indicator decreased. In the other words, there was an expressive variation. Thus, there is a great difference between negative and positive inoculation factors. In the first evaluation time (50 DAE), NI and PI behaved different. It was then possible to observe impacts of inoculation on this experiment, especially for [80+40] $\mathrm{N}$ parceling.

Figure 3. Interaction effects among treatments (positive inoculation - PI and negative inoculation - NI, and N parceling [60+60] or [80+40] $\mathrm{kg} \mathrm{ha}^{-1}$ of N urea), time, and net photosynthesis (A) (a) and stomatal conductance (Gs) (b) of common beans (Phaseolus vulgaris L.). Average data performed on surface design. Red and blue represent low and high values, respectively.

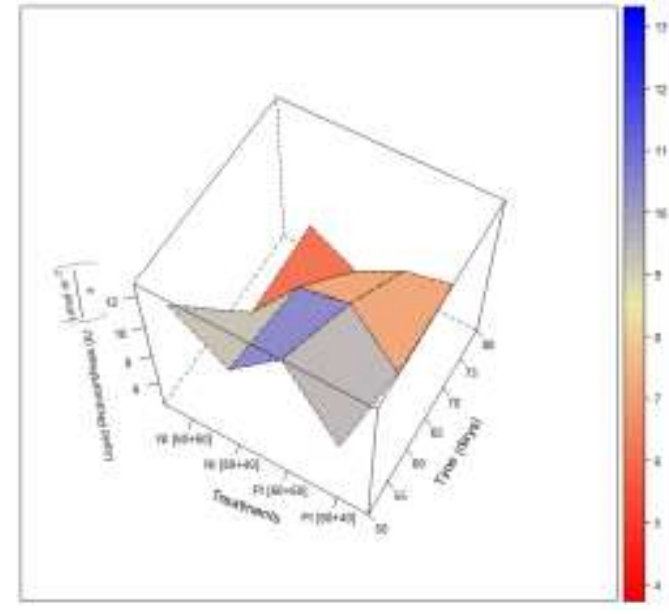

(a)

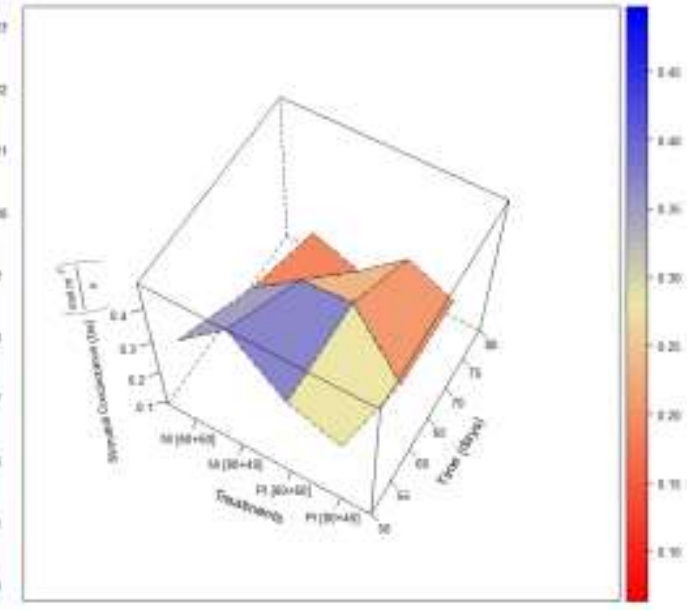

(b)

Source: Authors.

In this study, transpiration (E) demonstrated effects among treatments over time (Table 2) and interactions (Table 2 and Figure 4a). The NI treatments were the most affected by transpiration (E), especially [60+60] N parceling, which performed differently in this experiment (Figure 4a). The PI [80 + 40] treatment performed similar as NI [60+60], but with lower proportions and variations $(\Delta)$. Comparing the start and the end of evaluation, it is possible to state that the treatment behaves exactly the opposite (Figure $4 \mathrm{a}$ ). 
Figure 4. Interaction effects among treatments (positive inoculation - PI and negative inoculation - NI, and N parceling $[60+60]$ or $[80+40] \mathrm{kg} \mathrm{ha}^{-1}$ of $\mathrm{N}$ urea), time, and transpiration (A) (a) and internal $\mathrm{CO}_{2}$ concentration $\left(\mathrm{C}_{\mathrm{i}}\right)$ (b) of common beans (Phaseolus vulgaris L.). Average data performed on surface design. Red and blue represent low and high values, respectively.

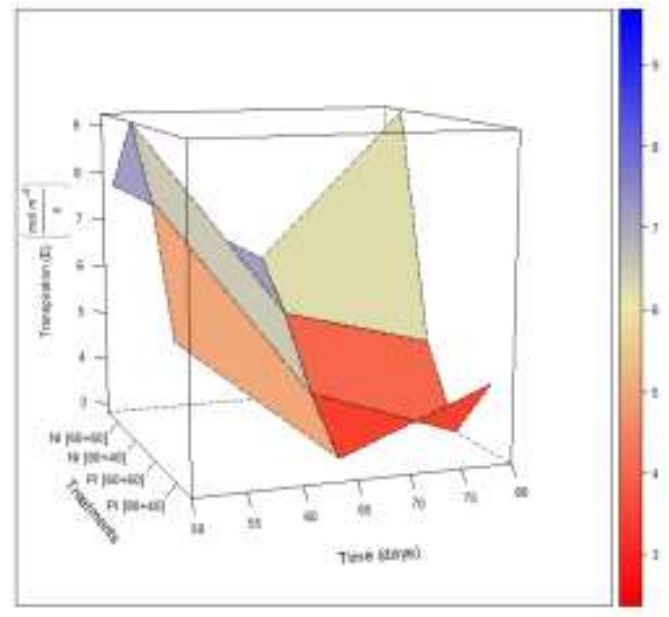

(a)

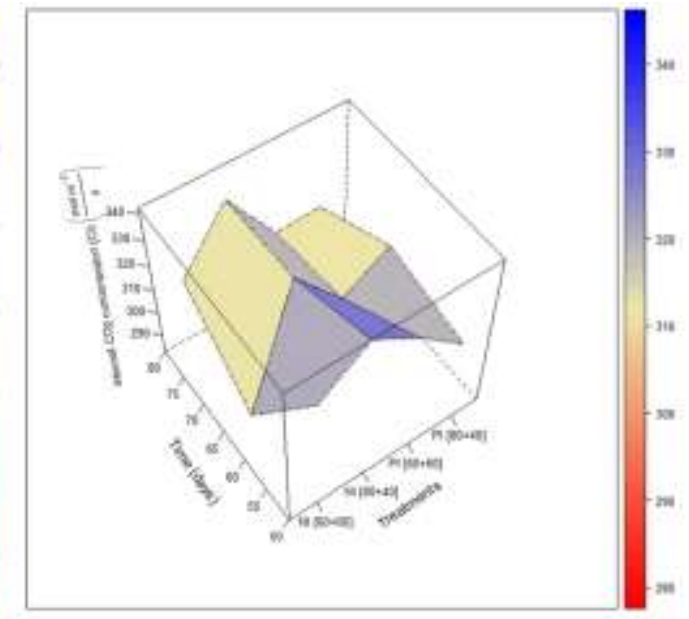

(b)

Source: Authors.

The internal $\mathrm{CO}_{2}$ concentration $(\mathrm{Ci})$ was not significantly different than no other factor evaluated in this study (Table 2). Despite this result, Figure $4 \mathrm{~b}$ shows some singular differences among treatments which the statistic model could not put on evidence. In this case, $\mathrm{NI}[80+40]$ was the treatment with the highest internal $\mathrm{CO}_{2}$ concentration at the start of evaluation. As time passed, the levels decreased. This treatment was also the one with the highest $\mathrm{CO}_{2}$ concentration in this study (Figure $4 \mathrm{~b}$ ), even without significance among data.

There were some intercorrelations among physiological parameters (Figure 5). We proposed positive and negative interactions from the data. The strongest positive interaction was signalized by stomatal conductance (Gs), net photosynthesis rate (A), and internal $\mathrm{CO}_{2}$ concentration ( $\mathrm{Ci}$ ). $\mathrm{RCI}$ had strong positive correlation with $\mathrm{Ci}$, but the opposite happened with $\mathrm{A}$. Transpiration (E) had a weak positive relation with the majority of parameters, as well as with Gs. However, Fv/Fm had a negative correlation with the parameters, except for Gs, as already reported. 
Figure 5. Correlation network for physiological measurements. The relative thickness and color density of the bands indicate the strength of Pearson's $r$. The color of each band indicates a positive (green) or negative (red) correlation.

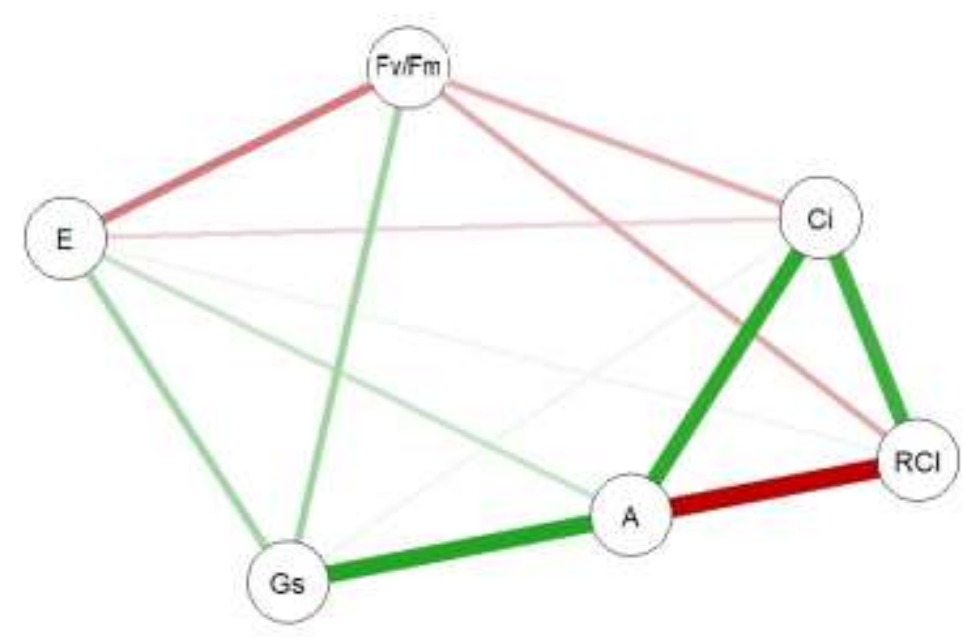

Source: Authors.

\subsection{Efficiency of root nodulation and grain yield of common bean}

In non-inoculated treatments (NI), matter nodule dry (MDN) was 35\% lower per plant than in inoculated treatments (PI) (Table 3). Concerning the number of nodules (NN) per plant, the PI treatment was superior by $54 \%$. On the other hand, the productivity of the NI treatment was higher by around 15\% than that of the PI. N parceling did not affect NN and productivity significantly, but [80+40] $\mathrm{kg}_{\text {of }} \mathrm{N} \mathrm{ha}^{-1}$ improved the MDN per plant (Table 3). The treatments did not show an interaction for this variable. The nitrogen fertilizer splitting did not affect productivity.

Table 3. Nodule dry matter, number of nodules, and productivity of common beans (Phaseolus vulgaris L.) in function of seed inoculation and nitrogen fertilization splitting.

\begin{tabular}{lccc}
\hline Treatments & MDN & NN & Productivity \\
\hline Inoculation (I) & g plant $^{-1}$ & plant $^{-1}$ & $\mathrm{~kg} \mathrm{ha}^{-1}$ \\
Negative (NI) & $14 \mathrm{~b}$ & $21.35 \mathrm{~b}$ & $3737.36 \mathrm{a}$ \\
Positive (PI) & $19 \mathrm{a}$ & $38.98 \mathrm{a}$ & $3251.46 \mathrm{~b}$ \\
F-test & $17.48^{* *}$ & $56.41^{* *}$ & $11.68^{* *}$ \\
Subdivision of N (N) & & & \\
{$[60+60]$} & $14 \mathrm{~b}$ & $28.6 \mathrm{a}$ & $3485.39 \mathrm{a}$ \\
{$[80+40]$} & $18 \mathrm{a}$ & $31.73 \mathrm{a}$ & $3503.43 \mathrm{a}$ \\
F-test & $12.63^{* *}$ & $1.78^{\mathrm{ns}}$ & $0.02^{\mathrm{ns}}$ \\
Interaction IxN - F & $0.39^{\text {ns }}$ & $0.28^{\text {ns }}$ & $0.56^{\mathrm{ns}}$ \\
\hline Mean General & 0.16 & 30.17 & 3494.41 \\
C.V $(\%)$ & 14.28 & 15.55 & 8.13 \\
\hline
\end{tabular}

Means followed by the same letter on lines do not differ by Tukey test at $5 \%$ probability. CV: Coefficient of variation $*$ and ${ }^{\text {ns. }}$ significant at $1 \%$ and not significant at $5 \%$ probability by F-test, respectively. Source: Authors. 


\section{Discussion}

\subsection{Nutritional status and maximum photochemical efficiency of common bean photosystem II}

The plots that received initially more $\mathrm{N}[80+40] \mathrm{kg} \mathrm{ha}^{-1}$ showed a higher RCI. This effect can be attributed to the role of nitrogen as a constituent of chlorophyll pigments (Soratto et al., 2004). Thus, the high RCI values observed in these treatments may indicate a type of accumulation on this first step of crop production. It is also a technical indicative of an efficient $\mathrm{N}$ application to common beans. Apparently, there is a strong relation between $\mathrm{N}$ mineral input on the first stage of crop production and biological nitrogen fixation (BNF). Soratto et al. (2004) also argued for this situation. The authors proposed a comparison between conventional and no-tillage systems. They observed findings similar as ours.

In this study, the results show a change in RCI behavior as time passed, and then a maximum performance at $80 \mathrm{DAE}$ (R8 stage). The common bean depends on fertilization inputs until the third vegetative stage (V3). After that, nodule formation starts. Normally, plants demand high volumes of nutrients between the V4 and R5 stages, including N, which is essential to improve total biomass. At the R5 and R8 stages, there is a fast accumulation of nutrients. The reduction of root activities is common with carbohydrates translocation, mainly during pod formation (Oliveira et al., 2018).

After the R8 stage, chlorophyll content decreases in order to export amino acids to grains. Then, the photosynthetic activity decreases (Buchanan-Wollaston, 1997). There is a response of RCI over time in beans (Pérola cultivar), as Da Silveira et al. (2003) and Barbosa Filho et al. (2008) have reported.

Nitrogen content was considered adequate for beans (Ambrosano et al., 1997; Malavolta et al., 1997). However, the inoculated treatments (PI) presented a higher nitrogen content in leaves compared to plants with no inoculation (NI). Inoculated plants may have stood out in relation to non-inoculated ones because, in addition to the dose of $20 \mathrm{~kg} \mathrm{ha}^{-1} \mathrm{~N}$ applied at sowing in both treatments, inoculation with $\mathrm{N}$-fixing bacteria may have favored the accumulation of $\mathrm{N}$ in leaves by using BFN (Binotti et al., 2009).

Over time, the leaf $\mathrm{N}$ content decreased linearly until reaching its lowest value at 80 DAE. During the entire period of plant development, nitrogen is absorbed from the soil, accumulated, and remobilized in vegetative tissues (Ta \& Weiland, 1992). Therefore, cells and proteins deteriorate and renew, causing a natural aging of leaves, which is called senescence. Senescence is the final stage of leaf development (Gan \& Amasino, 1997). It is a highly regulated process. However, the exact sequence of events that interfere with its onset has not yet been elucidated (Buchanan-Wollaston, 1997).

During the senescence phase, nitrogen metabolism changes. It passes through a gradual transition between assimilation phases up to remobilization (Feller \& Fischer, 1994). It is possible to observe marked changes in the activity and expression of enzymes involved in this process, such as a decrease in the activities of the enzyme nitrate reductase (NR) during the initial stages of senescence (Feller \& Fischer, 1994). During the senescence phase, nitrogen is remobilized mainly from leaves to the drain regions of the plant, such as flowers and seeds (Borrell and Hammer, 2000).

In short, the nutrients the roots absorb are not sufficient to supply the total needs of grains. Thus, the preservation of leaf metabolism at this stage is important in order to provide the best grain development. As the plant still benefits, albeit to a lesser extent, from the net photosynthesis rate (Ta \& Weiland, 1992), the RCI increases. In contrast, the decrease in the N content in beans may reflect this performance.

As for maximum photochemical efficiency, studies have not defined specific values for bean crops. In general, it is assumed that when the photosynthetic apparatus is intact, its Fv/Fm values vary between 0.75 and 0.85 electrons quantum ${ }^{-1}$ (de Reis \& Campostrini, 2008; dos Santos et al., 2010; Suassuna et al., 2010). The Fv/Fm index expresses the efficiency of excitation energy captured by open reaction centers of the photosystem II (PSII) (Krause, 1988). It can therefore represent the photochemical efficiency of electron transport. Plants without inoculation and with the lowest $\mathrm{N}$ partial dose in the first 20 
days presented better $\mathrm{Fv} / \mathrm{Fm}$ values (0.75). These values are within the limits considered adequate, indicating that the photosynthetic apparatus is at its ideal state.

Inoculated plants exposed to the greatest availability of $\mathrm{N}$ in the first days and those that received the nitrogen fertilization splitting of $80+40 \mathrm{~kg}$ of $\mathrm{N}$ per hectare at 20 and $40 \mathrm{DAE}$ presented $\mathrm{Fv} / \mathrm{Fm}$ values of 0.74 , which are below the ideal range. The decrease in the rates of maximum photochemical efficiency is a result of the reduction of the fraction of reaction centers existing in the PSII, which causes a decrease in photochemical reactions (Baker, 2004). Ecophysiological studies have suggested that the presence of natural or induced stress of abiotic or abiotic nature decreases Fv/Fm (Baker, 2008).

Pérez et al. (2005) observed that the stress index ( Fv/Fm) increased with the highest supply of nitrogen. This $\mathrm{N}$ is reversed in components of the photosynthetic apparatus, which causes a greater activity of RuBisCO (Pérez et al., 2005). In the present study, the index in plants with a higher nitrogen supply decreased during their initial development, thus proving that they were under stressful development conditions. Therefore, the addition of nitrogen to the system can stimulate stress conditions, which can trigger other plant metabolic processes.

By evaluating only the development of maximum efficiency of the PSII and regardless of other treatments (inoculation and parceling of nitrogen fertilization), plants presented in the evaluations at 50 and $65 \mathrm{DAE} \mathrm{a} \mathrm{Fv} / \mathrm{Fm}$ of 0.75 . This value is at the lowest limit of the range concentration considered ideal. In the last evaluation, at $80 \mathrm{DAE}$, the index decreased to 0.73 , which is outside the ideal range and denotes a greater plant stress. There was also an interaction between evaluation period and nitrogen fertilization splitting $\left(80+40 \mathrm{~kg} \mathrm{ha}^{-1}\right.$ of $\left.\mathrm{N}\right)$. In the first two evaluations, the index was 0.75 ; in the last evaluation, it was 0.71 . The decrease in this index indicates that after $80 \mathrm{DAE}$, beans were under stress. This can be explained by the coincidence of this period with the R8 stage of the crop, in which grain filling occurs when the processes of leaf senescence and physiological drain begin (Davies \& Zhang, 1991).

\subsection{Physiological attributes of common bean gas exchange}

Beans, cultivar Pérola, presented a higher transpiratory rate in inoculated plants. It differed from what happened to stomatal conductance and liquid photosynthesis rate, which showed high values for plants with no inoculation. In addition, the physiological behavior, including transpiration (E), stomatal conductance (Gs), and liquid photosynthesis rate (A), was similar. This shows an interrelationship between these attributes. Studies have pointed to transpiration as a byproduct of photosynthetic $\mathrm{CO}_{2}$ absorption ( Monteith, 1988; Kramer, 1995). In addition to its important role in net photosynthesis rate, large variations in this rate, at which water is absorbed for each mole of assimilated $\mathrm{CO}_{2}$ and there is evidence of substantial nocturnal transpiration in photosynthetically inactive C3 and C4 plants (Caird et al., 2007; Kupper et al., 2012), suggest that transpiration plays an important functional role in plants.

In addition to facilitating the cooling of leaves (Nobel, 2009; Parkhurst \& Loucks, 1972) and roots due to the transport of solutes (Tanner \& Beevers, 1990; Tanner \& Beevers, 2001;), transpiration also drives the movement of water and dissolved nutrients to surface roots via mass flows (Cramer et al., 2008, 2009). Matimati et al. (2014) verified the effects of nitrogen fertilization on bean water flow and observed that the closer the nitrogen mineral fertilizer was to the roots, the higher the transpiratory rates of the crop. The more unavailable the element was for the plant (more distant from roots), the less its transpiration.

Thus, as it was possible to observe in this experiment, it is possible to infer that the greater transpiration in inoculated plants and in plants in which the nitrogen fertilization splitting was uniform (60+60 $\mathrm{kg} \mathrm{ha}^{-1}$ at 20 and $\left.40 \mathrm{DAE}\right)$ allowed a greater possibility of access to $\mathrm{N}$ via mass flow. A greater distance from the last fertilization date decreases transpiration, as 
did the $\mathrm{N}$ leaf content. Other authors (Garrish et al., 2010) have concluded that plant water flows vary depending on the leaf $\mathrm{N}$ content at a given vapor pressure deficit, suggesting that the higher $\mathrm{N}$ content in the cytosol may modulate water flows.

According to Westgate e Boyer (1986), the peak of net photosynthesis rate in common beans occurs at flowering (pollination) and pod formation. During this phase, the plant is at its metabolic maximum. After that, there is a decrease in photosynthetic rates. At this stage, the net $\mathrm{CO}_{2}$ assimilation rate increases (Pimentel et al., 1999), leading to greater leaf carbohydrate reserves, which can then support embryo growth after pollination (Schussler \& Westgate, 1994; Kramer, 1995). This explains the results found in the present work: the photosynthetic rates decreased after $50 \mathrm{DAE}$, a moment that represents the stage of flowering of beans, cultivar Pérola. Therefore, as a reflex, there was a reduction in stomatal conductance.

According to Flexas e Medrano (2002), the decrease in net photosynthesis rate is influenced by the reduction in stomatal conductance and causes biochemical losses. The latter is a reduction in photosynthetic metabolism due to a decrease in the regeneration capacity of the ribulose 1,5-bisphosphate (RuBP) in chloroplasts. The decrease in stomatal conductance over time, the results found in this experiment, and the decrease in $\mathrm{Fv} / \mathrm{Fm}$ indexes may reflect the limitations of the net photosynthesis rate imposed by stomatal closure. (Long \& Humphries, 1994; Krause, 1988) reached this same conclusion. Long et al. (1994) reported that this dynamic can promote an imbalance between photochemical reactions and PSII activity, which requires electron transport for net photosynthesis rates, thus leading to overexcitation and subsequent photoinhibition damage from PSII reaction centers.

\subsection{Efficiency of root nodulation and grain yield of common bean}

We observed that the different subdivisions did not result in significant differences in the number of nodules per plant in roots. The dry matter of nodules of plants submitted to the splitting of $80+40 \mathrm{~kg}$ of nitrogen per hectare reached a mean higher than that of plants submitted to the other splitting. The values were still close to those found in inoculated plants. All treatments showed a NN above 15 nodules plant ${ }^{-1}$, which indicates a good symbiotic efficiency (Cardoso et al., 2009).

According to Cassini (2014), nodulation can be affected by environmental conditions such as temperature, humidity, soil acidity, among others. The addition of mineral nitrogen sources can also result in a decrease in the efficiency of BFN. Studies have indicated that, in the presence of nitrogen fertilizer, the nodulation stimulus decreases because the fertilizer $\mathrm{N}$ is readily available and the energy demand for BFN is high, representing one of the most expensive metabolic processes for the plant. Thus nitrogen is preferably absorbed by roots (Hungria et al., 2003; Moreira \& Siqueira, 2006)

Hungria et al. (2003) evaluated the effects of inoculation and addition of nitrogen fertilizer to common beans (cv. IAPAR 14) and observed that the application of $30 \mathrm{~kg} \mathrm{ha}^{-1}$ of $\mathrm{N}$ at sowing provided a decrease in the nodulation of bean plants. Valadão et al. (2009) reported that the $\mathrm{N}$ supplied by fertilization $\left(10 \mathrm{~kg} \mathrm{ha}^{-1}\right.$ of $\mathrm{N}$ at sowing $+50 \mathrm{~kg} \mathrm{ha}^{-1}$ of cover $\left.\mathrm{N}\right)$ reduced the establishment of symbiont bacteria, thus negatively affecting NN and MDN. (de Souza et al., 2011) concluded that the increase in $\mathrm{N}$ doses in cover decreases $\mathrm{NN}$ and DMN in common beans cultivated using the no-tillage system in succession to winter crop corn intercropped with Urochloa.

Non-inoculated bean also presented nodulation, albeit at a lower weight and quantity, compared to inoculated beans. This can show the existence of an abundant indigenous population on the soil adapted to tropical conditions (Long \& Humphries, 1994; Grange \& Hungria, 2004; de Brito et al., 2015). According to Vlassak et al. (1996) and da Silveira et al. (2003), most soils with a history of bean cultivation contain native rhizobia that can interfere with the establishment and effectiveness of inoculated strains, reducing responses to inoculation and being able to carry out nodulation in non-inoculated plants inserted into the system.

Non-inoculated plants, regardless of the other treatments applied, showed a higher general productivity, reaching $3,737.36 \mathrm{~kg} \mathrm{ha}^{-1}$. Nitrogen fertilization splitting (independent of inoculation) did not show significant differences regarding 
productivity. Brazilian soils have a high amount of native rhizobia in the soil, especially in areas with successive bean cultivation, and a wide genetic variability (Hungria et al., 2000). Native rhizobia can be more adapted and more competitive to inoculated strains, reducing the efficiency of commercial inoculants (Grange \& Hungria, 2004).

In areas without previous cultivation of beans in Planaltina, DF, Brazil, the indigenous populations of rhizobia were few. High yields could be achieved only using seed inoculation. However, in a soil previously cultivated with beans with a great population of native rhizobia, the formation of nodules by inoculated strains was limited, requiring supplementation with a nitrogen fertilizer to obtain higher yields (Vargas et al., 2000). Vlassak et al. (1996) evaluated the Seropédica area (RJ, Brazil), which has no history of bean crops, and found that inoculation with rhizobia resulted in increases in nodulation and nitrogenase activity in the root system in the first year of cultivation. However, the reintroduction of the inoculant in the third year of planting did not affect it, since the rhizobia population in the area increased from $30 \mathrm{~g}^{-1}$ soil cells in the first year to 104 $\mathrm{g}^{-1}$ soil cells in the third year. This evidence indicates that the productivity of inoculated beans can be negatively affected by the presence of native strains of rhizobia.

\section{Conclusion}

Common bean submitted to inoculation of seeds presents a leaf nitrogen content $5 \%$ superior to that of non-inoculated ones. The physiological variables associated with gas exchange, transpiration, and net photosynthesis rate are higher in inoculated plants using the splitting of $60+60 \mathrm{~kg} \mathrm{ha}^{-1}$ of $\mathrm{N}$.

Areas with successive cultivation of beans with inoculated seeds tend to maintain the population of rhizobacteria even after a fallow period. The areas can nodulate roots of non-inoculated bean plants, thus presenting a greater number of nodules and dry mass of nodules.

The inoculation of common beans under the conditions of the present study provides a greater physiological quality as for gas exchange.

The nitrogen fertilization splitting does not influence bean productivity: $3,494.41 \mathrm{~kg} \mathrm{ha}^{-1}$ were obtained by applying $120 \mathrm{~kg} \mathrm{ha}^{-1}$ of nitrogen covering the beans, cultivar Pérola. The application of $120 \mathrm{~kg} \mathrm{ha}^{-1}$ of cover nitrogen under the conditions of the present study reduces the efficiency of BNF in irrigated Pérola beans, thus causing a 13\% decrease in final grain yield in relation to inoculated plants. Therefore, future studies on nitrogen fertilization and inoculation of common beans are necessary to evaluate their influence on the diversity of native rhizobia in tropical soils.

\section{Acknowledgments}

The authors would like to thank the funding provided by the Coordination of Superior Level Staff Improvement (CAPES) and National Council for Science and Technology (CNPq). AFA and AMB would like to thank CAPES for the funds provided from the SD (National Program of Social Demand). RAF would like to thank CNPq for the PQ funds process number 306329/2019-0.

\section{References}

Alvares, C. A., Stape, J. L., Sentelhas, P. C., De Moraes Gonçalves, J. L., \& Sparovek, G. (2013). Köppen’s climate classification map for Brazil. Meteorologische Zeitschrift, 22(6), 711-728. https://doi.org/10.1127/0941-2948/2013/0507

Alves, B. J. R., Smith, K. A., Flores, R. A., Cardoso, A. S., Oliveira, W. R. D., Jantalia, C. P., Urquiaga, S., \& Boddey, R. M. (2012). Selection of the most suitable sampling time for static chambers for the estimation of daily mean N $2 \mathrm{O}$ flux from soils. Soil Biology and Biochemistry, 46, 129-135. https://doi.org/10.1016/j.soilbio.2011.11.022

Ambrosano, E. J., Tanaka, R. T., Mascarenhas, A. A., Van Raij, B., Quaggio, J. Á. \& Cantarella, H. (1997). Leguminosas e oleaginosas. In Raij Van, B., Cantarela, H., Quaggio, J. A., Furlani (Ed.), Recomendações de adubação e calagem para o Estado de São Paulo (2nd ed., pp. 189-203). IAC. 
Azevedo, P. V. de, Soares, J. M., Silva, V. de P. R. da, Silva, B. B. da, \& Nascimento, T. (2008). Evapotranspiration of “Superior” grapevines under intermittent irrigation. Agricultural Water Management, 95(3), 301-308. https://doi.org/10.1016/j.agwat.2007.10.011

Baker, N. R. \& Oxborough, K. (2004). Chlorophyll fluorescence as a probe of photosynthetic productivity. In Beatty, J. F., Thomas, G., Howard, A. (Ed.), Advances in Photosynthesis and Respiration (pp. 65-82). Springer.

Baker, N. R. (2008). Chlorophyll Fluorescence: A probe of photosynthesis in vivo. Annual Review of Plant Biology, 59(1), 89-113. https://doi.org/10.1146/annurev.arplant.59.032607.092759

Barbosa Filho, M. P., Cobucci, T., Fageria, N. K., \& Mendes, P. N. (2008). Determinação da necessidade de adubação nitrogenada de cobertura no feijoeiro irrigado com auxílio do clorofilômetro portátil. Ciencia Rural, 38(7), 1843-1848. https://doi.org/10.1590/S0103-84782008000700007

Barbosa, J. C., \& Maldonado Júnior, W. (2015). AgroEstat: Sistema para análises estatísticas de ensaios agronômicos. Faculdade de Ciências Agrárias e Veterinárias UNESP.

Binotti, F. F. da S., Arf, O., de Sá, M. E., Buzetti, S., Alvarez, A. C. C., \& Kamimura, K. M. (2009). Fontes, doses e modo de aplicação de nitrogênio em feijoeiro no sistema plantio direto. Bragantia, 68(2), 473-481. https://doi.org/10.1590/s0006-87052009000200022

Borrell, A. K., \& Hammer, G. L. (2000). Nitrogen dynamics and the physiological basis of stay-green in Sorghum. Crop Science, 40(5), 1295-1307. https://doi.org/10.2135/cropsci2000.4051295x

Buchanan-Wollaston, V. (1997). The molecular genetic analysis of leaf senescence. Journal of Experimental Botany, 8(2), 200-207. https://doi.org/10.1016/S0958-1669(97)80103-6

Caird, M. A., Richards, J. H., \& Donovan, L. A. (2007). Nighttime stomatal conductance and transpiration in C3 and C4 plants. Plant Physiology, 143(1), 4 10. https://doi.org/10.1104/pp.106.092940

Cardoso, J. D., Gomes, D. F., Goes, K. C. G. P., Fonseca, N. da S., Dorigo, O. F., Hungria, M., \& Andrade, D. S. (2009). Relationship between total nodulation and nodulation at the root crown of peanut, soybean and common bean plants. Soil Biology and Biochemistry, 41(8), 1760-1763. https://doi.org/10.1016/j.soilbio.2009.05.008

Carvalho, M. A. C., Arf, O., Sá, M. E., Buzetti, S., Santos, N. C. B., \& Bassan, D. A. Z. (2001). Produtividade e qualidade de sementes de feijoeiro (Phaseolus vulgaris L.) sob influência de parcelamentos e fontes de nitrogênio. Revista Brasileira de Ciência Do Solo, 25(3), 617-624. https://doi.org/10.1590/s010006832001000300010

Casaroli, D., Rodrigues, T. R., Martins, A. P. B., Evangelista, A. W. P., \& Júnior, J. A. (2018). Rainfall and evapotranspiration patterns in Goiânia, GO. Revista Brasileira de Meteorologia, 33(2), 247-256. https://doi.org/10.1590/0102-7786332004

Cassini, S. T. A. \& Franco, M. C. (2014). Fixação biológica de nitrogênio: microbiologia, fatores ambientais e genéticos. In: Vieira, A., Paula-Júnior, C., Borém J. (Ed.), Feijão (2nd ed., p. 600).

Christiansen, J. E. (1942). Irrigation by sprinkling (Berkeley:). University of California Agricultural Experiment Station.

Cramer, M. D., Hawkins, H. J., \& Verboom, G. A. (2009). The importance of nutritional regulation of plant water flux. Oecologia, 161(1), 15-24. https://doi.org/10.1007/s00442-009-1364-3

Cramer, M. D., Hoffmann, V., \& Verboom, G. A. (2008). Nutrient availability moderates transpiration in Ehrharta calycina. New Phytologist, 179(4), 10481057. https://doi.org/10.1111/j.1469-8137.2008.02510.x

da Silveira, P. M., Braz, A. J. B. P., \& Didonet, A. D. (2003). Uso do clorofilômetro como indicador da necessidade de adubação nitrogenada em cobertura no feijoeiro. Pesquisa Agropecuaria Brasileira, 38(9), 1083-1087. https://doi.org/10.1590/s0100-204x2003000900009

Davies, W. J., \& Zhang, J. (1991). Root signals and the regulation of growth and development of plants in drying soil. Annual Review of Plant Physiology and Plant Molecular Biology, 42(1), 55-76. https://doi.org/10.1146/annurev.pp.42.060191.000415

de Brito, L. F., Pacheco, R. S., de Souza Filho, B. F., Ferreira, E. P. de B., Straliotto, R., \& Araújo, A. P. (2015). Resposta do feijoeiro comum à inoculação com rizóbio e suplementação com nitrogênio mineral em dois biomas brasileiros. Revista Brasileira de Ciencia Do Solo, 39(4), 981-992. https://doi.org/10.1590/01000683rbcs20140322

Delgado-Vargas, F., Jimenez, A. R., \& Paredes-Lopez, O. (2010). Critical Reviews in Food Science and Nutrition. Natural Pigments: Carotenoids, Anthocyanins, and Betalains - Characteristics, Biosynthesis, Processing, and Stability. In Critical Reviews in Food Science and Nutrition, 40(3).

de Reis, F. O., \& Campostrini, E. (2008). Trocas gasosas e eficiência fotoquímica potencial em mamoeiro do grupo "formosa" cultivado em condição de campo. Bragantia, 67(4), 815-822. https://doi.org/10.1590/s0006-87052008000400002

de Souza, E. de F. C., Soratto, R. P., \& Pagani, F. A. (2011). Aplicação de nitrogênio e inoculação com rizóbio em feijoeiro cultivado após milho consorciado com braquiária. Pesquisa Agropecuaria Brasileira, 46(4), 370-377. https://doi.org/10.1590/S0100-204X2011000400005

dos Santos, A. B., Fageria, N. K., Da Silva, O. F., \& De Melo, M. L. B. (2003). Resposta do feijoeiro ao manejo de nitrogênio em várzeas tropicais. Pesquisa Agropecuaria Brasileira, 38(11), 1265-1271. https://doi.org/10.1590/s0100-204x2003001100003

Epstein, E Bloom, A. (2004). Nutrição mineral de plantas: princípios e perspectivas (2nd ed.). Editora Planta.

Fageria, N. K., \& Baligar, V. C. (2005). Enhancing nitrogen use efficiency in crop plants. Advances in Agronomy, 88(05), 97-185. https://doi.org/10.1016/S0065-2113(05)88004-6 
Feller, U., \& Fischer, A. (1994). Nitrogen metabolism in senescing leaves. In Critical Reviews in Plant Sciences (Vol. 13, Issue 3). https://doi.org/10.1080/07352689409701916

Ferreira, A. N., Arf, O., de Carvalho, M. A. C., Araújo, R. S., de Sá, M. E., \& Buzetti, S. (2000). Estirpes de Rhizobium tropici na inoculação do feijoeiro. Scientia Agricola, 57(3), 507-512. https://doi.org/10.1590/S0103-90162000000300021

Flexas, J., \& Medrano, H. (2002). Drought-inhibition of photosynthesis in C3 plants: Stomatal and non-stomatal limitations revisited. Annals of Botany, 89(2), 183-189. https://doi.org/10.1093/aob/mcf027

Flores, R. A., da Cunha, P. P., Damin, V., Abdala, K. de O., Maranhão, D. D. C., dos Santos, M. M., Neto, L. R. G., Donegá, M. C., \& Rodrigues, R. A. (2019). Physiological quality and grain production of Phaseolus vulgaris (cv. BRS Pérola) using boron (B) application under irrigatation system. Australian Journal of Crop Science, 13(4), 520-528. https://doi.org/10.21475/ajcs.19.13.04.p1383

Flores, R. A., Rodrigues, R. A., da Cunha, P. P., Damin, V., Arruda, E. M., de Oliveira Abdala, K., \& Donegá, M. C. (2018). Grain yield of phaseolus vulgaris in a function of application of boron in soil. Journal of Soil Science and Plant Nutrition, 18(1), 144-156. https://doi.org/10.4067/S0718-95162018005000701

Flores, R. A., Silva, R. G. da, Cunha, P. P. da, Damin, V., Abdala, K. de O., Arruda, E. M., Rodrigues, R. A., \& Maranhão, D. D. C. (2017). Economic viability of Phaseolus vulgaris (BRS Estilo) production in irrigated system in a function of application of leaf boron. Acta Agriculturae Scandinavica Section B: Soil and Plant Science, 67(8), 697-704. https://doi.org/10.1080/09064710.2017.1329454

Gan, S., \& Amasino, R. M. (1997). Making sense of senescence: Molecular genetic regulation and manipulation of leaf senescence. Plant Physiology, 113(2), 313-319. https://doi.org/10.1104/pp.113.2.313

Garrish, V., Cernusak, L. A., Winter, K., \& Turner, B. L. (2010). Nitrogen to phosphorus ratio of plant biomass vers us soil solution in a tropical pioneer tree, Ficus insipida. Journal of Experimental Botany, 61(13), 3735-3748. https://doi.org/10.1093/jxb/erq183

Gilmour, J. T., \& Mauromoustakos, A. (2011). Nitrogen mineralization from soil organic matter: a sequential model. Soil Science Society of America Journal, 75(1), 317-323. https://doi.org/10.2136/sssaj2010.0123

Gonzaga, A. C. de O. (2014). Feijão - O produtor pergunta, a Embrapa responde. Embrapa.

Grange, L., \& Hungria, M. (2004). Genetic diversity of indigenous common bean (Phaseolus vulgaris) rhizobia in two Brazilian ecosystems. Soil Biology and Biochemistry, 36(9), 1389-1398. https://doi.org/10.1016/j.soilbio.2004.03.005

Hungria, M., Andrade, D. D. S., Chueire, L. M. D. O., Probanza, A., Guttierrez-Mañero, F. J., \& Megías, M. (2000). Isolation and characterization of new efficient and competitive bean (Phaseolus vulgaris L.) rhizobia from Brazil. Soil Biology and Biochemistry, 32(11-12), 1515-1528. https://doi.org/10.1016/S0038-0717(00)00063-8

Hungria, M., Campo, R. J., \& Mendes, I. C. (2003). Benefits of inoculation of the common bean (Phaseolus vulgaris) crop with efficient and competitive Rhizobium tropici strains. Biology and Fertility of Soils, 39(2), 88-93. https://doi.org/10.1007/s00374-003-0682-6

Kaschuk, G., Hungria, M., Andrade, D. S., \& Campo, R. J. (2006). Genetic diversity of rhizobia associated with common bean (Phaseolus vulgaris L.) grown under no-tillage and conventional systems in Southern Brazil. Applied Soil Ecology, 32(2), 210-220. https://doi.org/10.1016/j.apsoil.2005.06.008

Kramer, P. J. \& Boyer, J. S. (1995). Stomata and gas exchange. In J. S. Kramer, P. J. \& Boyer, J. S. (Ed.), Water relations of plants (pp. 257-282). Academic Press.

Krause, G. H. (1988). Photoinhibition of photosynthesis. An evaluation of damaging and protective mechanisms. Physiologia Plantarum, 74(3), 566-574. https://doi.org/10.1111/j.1399-3054.1988.tb02020.x

Kupper, P., Rohula, G., Saksing, L., Sellin, A., Lõhmus, K., Ostonen, I., Helmisaari, H. S., \& Sõber, A. (2012). Does soil nutrient availability influence nighttime water flux of aspen saplings? Environmental and Experimental Botany, 82, 37-42. https://doi.org/10.1016/j.envexpbot.2012.03.013

Long, S. P., \& Humphries, S. (1994). Photoinhibition of. Annu. Rev. Plant Physiol. Plant Mol. Biol., 45, $633-662$.

Malavolta, E., Vitti, G. C. \& Oliveira, S. A. (1997). Avaliação do estado nutricional das plantas: princípios e aplicações (2nd ed.). Associação Brasileira para Pesquisa da Potássio e do Fosfato.

Matimati, I., Verboom, G. A., \& Cramer, M. D. (2014). Nitrogen regulation of transpiration controls mass-flow acquisition of nutrients. Journal of Experimental Botany, 65(1), 159-168. https://doi.org/10.1093/jxb/ert367

Monteith, J. L. (1988). Does transpiration limit the growth of vegetation or vice versa? Journal of Hydrology, 100(1-3), 57-68. https://doi.org/10.1016/00221694(88)90181-3

Moreira, F. M. S., \& Siqueira, J. O. (2006). Microbiologia e Bioquímica do Solo. Editora UFLA, ed. $2,729$.

Moreira, L. P., Oliveira, A. P. S., \& Ferreira, E. P. de B. (2017). Nodulation, contribution of biological $\mathrm{N}_{2}$ fixation, and productivity of the common bean (Phaseolus vulgaris L.) inoculated with rhizobia isolates. Australian Journal of Crop Science, 11(6), 644-651. https://doi.org/10.21475/ajcs.17.11.06.p310

Nobel, P. S. (2009). Physicochemical and environmental plant physiology (4th ed.). Academic Press.

Oliveira, A. P. S., Sousa, C. M., \& Ferreira, E. P. D. B. (2017). Performance of inoculated common bean in response to different cover crops and desiccation times. Revista Caatinga, 30(3), 642-652. https://doi.org/10.1590/1983-21252017v30n312rc

Oliveira, M. G. C., Oliveira, L. F. C., Wendland, A., Guimarães, C. M., Quintela, E. D., Barbosa, F. R., Carvalho, M. C. S., Junior, M. L., \& Silveira, P. M. 
(2018). Conhecendo a Fenologia do Feijoeiro e Seus Aspectos Fitotécnicos.

Pacheco, R. S., Brito, L. F., Straliotto, R., Pérez, D. V., \& Araújo, A. P. (2012). Seeds enriched with phosphorus and molybdenum as a strategy for improving grain yield of common bean crop. Field Crops Research, 136, 97-106. https://doi.org/10.1016/j.fcr.2012.07.017

Parkhurst, D. F., \& Loucks, O. L. (1972). Optimal leaf size in relation to environment. The Journal of Ecology, 60(2), 505. https://doi.org/10.2307/2258359

Pérez, P., Morcuende, R., Martín Del Molino, I., \& Martínez-Carrasco, R. (2005). Diurnal changes of Rubisco in response to elevated CO 2 , temperature and nitrogen in wheat grown under temperature gradient tunnels. Environmental and Experimental Botany, 53(1), 13-27. https://doi.org/10.1016/j.envexpbot.2004.02.008

Piaskowski, S. R., Ronzelli Júnior, P., Daros, E., \& Koehler, H. S. (2001). Adubação nitrogenada em cobertura para o feijoeiro em plantio direto na palha. Scientia Agraria, 2(1), 67. https://doi.org/10.5380/rsa.v2i1.979

Pimentel, C., Hébert, G., \& Da Silva, J. V. (1999). Effects of drought on $\mathrm{O}_{2}$ evolution and stomatal conductance of beans at the pollination stage. Environmental and Experimental Botany, 42(2), 155-162. https://doi.org/10.1016/S0098-8472(99)00030-1

Rocha, G. P. (2007). Programa de pós-graduação em biotecnologia. Bactérias associativas e simbiontes dos nódulos de Arachis pintoi (Leguminosae). Feira de Santana, BA.

Santos, C. M. dos, Rebelo, E., Jadoski, C. J., \& Emanuelle Dias dos Santos. (2010). Atividade fotossintética em alface (Lactuca sativa L.) submetidas a diferentes compostagens de resíduos agroindustriais. Pesquisa Aplicada \& Agrotecnologia, 3(3), 95-102.

Schussler, J. R., \& Westgate, M. E. (1994). Increasing assimilate reserves does not prevent kernel abortion at low water potential in maize. Crop Science, 34(6), 1569-1576. https://doi.org/10.2135/cropsci1994.0011183X003400060028x

Silva, da F. C. (2009). Manual de análises químicas de solos , plantas e fertilizantes. Embrapa Informação e Tecnologia.

Soratto, R. P., De Carvalho, M. A. C., \& Arf, O. (2004). Teor de clorofila e produtividade do feijoeiro em razão da adubação nitrogenada. Pesquisa Agropecuaria Brasileira, 39(9), 895-901. https://doi.org/10.1590/s0100-204x2004000900009

Sousa, D. M. G. de, \& Lobato, E. (2004). Cerrado: Correction of soil and fertilization. In Embrapa Cerrados (2 th).

Suassuna, J. F., Melo, A. S., Sousa, M. S. S., Costa, F. S., Fernandes, P. D., Pereira, V. M., \& Brito, M. E. B. (2010). Desenvolvimento e eficiência fotoquímica em mudas de híbrido de maracujazeiro sob lâminas de água | Bioscience Journal. Bioscience Journal, 4(1).

Ta, C. T., \& Weiland, R. T. (1992). Nitrogen Partitioning in Maize during Ear Development. Crop Science, 32(2), 443-451. https://doi.org/10.2135/cropsci1992.0011183x003200020032x

Tanner, W., \& Beevers, H. (2001). Transpiration, a prerequisite for long-distance transport of minerals in plants? Proceedings of the National Academy of Sciences of the United States of America, 98(16), 9443-9447. https://doi.org/10.1073/pnas.161279898

Tanner, W., \& Beevers, H. (1990). Does transpiration have an essential function in long-distance ion transport in plants? Plant, Cell \& Environment, 13(8), 745-750. https://doi.org/10.1111/j.1365-3040.1990.tb01089.x

Teixeira, P.C., Donagemma, G. K., Fontana, A., Teixeira, W. (2017). Manual of soil analysis methods; 3 th. Embrapa.

Valadão, F. C. de A., Jakelaitis, A., Conus, L. A., Borchartt, L., de Oliveira, A. A., \& Valadão, D. D. (2009). Inoculação das sementes e adubações nitrogenada e molíbdica do feijoeiro-comum, em Rolim de Moura, RO. Acta Amazonica, 39(4), 741-747. https://doi.org/10.1590/s0044-59672009000400002

Vlassak, K., Vanderleyden, J., \& Franco, A. (1996). Competition and persistence of Rhizobium tropici and Rhizobium etli in tropical soil during successive bean (Phaseolus vulgaris L.) cultures. Biology and Fertility of Soils, 21(1-2), 61-68. https://doi.org/10.1007/BF00335994

Walter, da C. M., José, A. J., Paulo, C. R. da C., Anderson, R. da S., Adão, W. P. E., \& Derblai, C. (2016). Nitrate and potassium leaching and the response of the common bean to different irrigation blades. African Journal of Agricultural Research, 11(34), 3188-3196. https://doi.org/10.5897/ajar2016.11299

Westgate, M. E., \& Boyer, J. S. (1986). Reproduction at low and pollen water potentials in maize. Crop Science, 26(5), 951-956. https://doi.org/10.2135/cropsci1986.0011183x002600050023x 